\title{
Production response in dairy cows milked two or three times a day: A meta-analysis
}

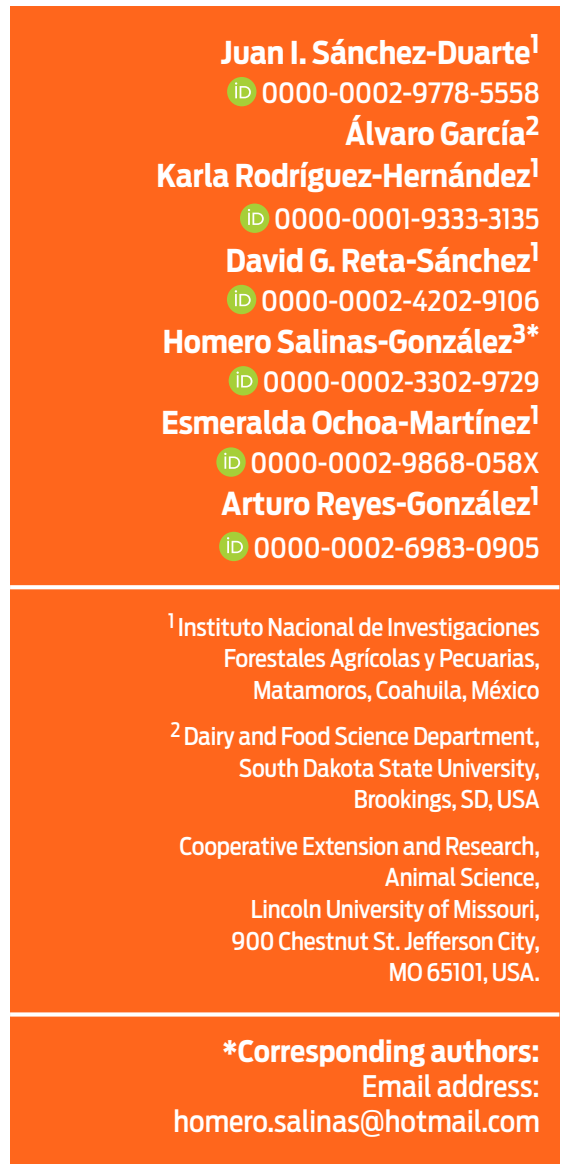

Accepted: 2020-05-06 Published: 2020-06-25

Additional information and declarations can be found on page 15

@) Copyright 2020 Juan I. Sánchez-Duarte et al.

open access $\boldsymbol{\odot}$

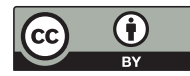

Distributed under Creative Commons CC-BY 4.0

\begin{abstract}
The objective was to evaluate the effects of two $(2 x)$ vs three $(3 x)$ times per day milking on milk production and milk composition in dairy cows. Fourteen scientific papers, containing production data from 16 trials, where dairy cows were milked $2 x$ or $3 x$, were analysed using meta-analysis with fixed and random-effects with the $R$ statistical program. The degree of heterogeneity and publication bias were measured with the $\mathrm{I}^{2}$ statistic and Begg's test, respectively. In addition, the meta-regression analysis explored other sources of heterogeneity for the response. The estimated effect size of $2 x$ and $3 \times$ milkings was calculated for dry matter intake (DMI), milk production, and milk composition. Dry matter intake, milk production, and milk fat and protein yields showed substantial heterogeneity $\left(R^{2}>50 \%\right)$. Whereas milk fat-percentage had moderate heterogeneity $\left(1^{2}<50 \%\right)$, and milk protein had no $\left(I^{2}=0 \%\right)$ heterogeneity. The year of publication, trial duration, and cattle breed did not influence production response parameters to milking frequency. We found no evidence of publication bias for the parameters evaluated (Begg's test; $P>$.05). Cows milked $2 \times$ produced less milk $(2.23 \mathrm{~kg} / \mathrm{d})$, less milk fat (0.06 $\mathrm{kg} / \mathrm{d})$, and less milk protein $(0.05 \mathrm{~kg} / \mathrm{d})$. In contrast, the fat percentage was lower (0.07 units) in $3 \times$, compared with $2 \times$ milking frequency. There was no effect of milking frequency on DMI and milk protein percentage. In conclusion, milk production and milk fat and protein yields improves as milking frequency increase from $2 x$ to $3 x$ daily, without affecting DMI. The implementation of $3 \times$ milking frequency must consider dairy cow management, labor, and milking parlour infrastructure, particular to each dairy farm.
\end{abstract}

Keywords: Milking frequency; Milk yield; Milk composition; Heterogeneity; Effect size

\section{Cite this as:}

Sánchez-Duarte JI, García Á, Rodríguez-Hernández K, Reta-Sánchez DG, Salinas-González H, Ochoa-Martínez E, Reyes-Conzález A. Production response in dairy cows milked two or three times a day: A meta-analysis. Veterinaria México OA. 2020;7(2). doi: 10.22201/ fmvz.24486760e.2020.2.562 


\section{Introduction}

One of the main objectives in dairy farming is to improve milk production and composition. Milking frequency can modify the quality and the amount of milk produced. The substantial increase in milk production, achieved through genetic selection, has compelled dairy producers to increase milking frequency. ${ }^{1,2}$ Research conducted under controlled conditions and on commercial dairy farms demonstrated a milk production increase $(1.72 \mathrm{~kg} / \mathrm{d})$ in cows milked $3 \times$ compared to those milked twice. This increase was accompanied by a decrease in body condition score. ${ }^{3}$ Similarly, milk protein yield increased $(0.15 \mathrm{~kg} / \mathrm{d})$ in cows milked $3 \times$, compared with $2 x$, as a result of the increased milk production. ${ }^{4}$ Likewise, milk fat yield also increases in thrice-daily milking. Indeed, Allen et al. ${ }^{5}$ and Atashi ${ }^{6}$ found that increasing the frequency of milking from $2 \times$ to $3 \times$, boosted milk production ( 3.46 and $3.69 \mathrm{~kg}$ milk/d) and milk fat yield $0.05 \mathrm{~kg} / \mathrm{d}$ and $0.11 \mathrm{~kg} / \mathrm{d}$ respectively. These and other studies are summarised in literature reports, ${ }^{1,7}$ showing the positive response of $3 \times$ vs $2 \times$ milking at different stages of lactation, and age (primiparous vs multiparous) of the cows. However, an effect of milking frequency on feed intake, parallel to those observed on milk composition and yield, remains debatable. Combining and analysing this information through a meta-analysis would add insight to the production benefits of this management alternative.

The meta-analysis is a powerful statistical tool to cumulate and summarise the knowledge in certain research fields. ${ }^{8}$ Through a meta-analysis, individual results are combined to identify the overall treatment effects. ${ }^{9}$ However, analysing data with a meta-analysis is not devoid of problems. Pooling data can create non-linear correlations, multifactorial rather than unifactorial effects, and limited coverage or non-homogeneous data that fails to connect results with the hypothesis tested. ${ }^{8}$ In contrast, meta-analysis produces effect size estimates with considerable statistical power compared to individual studies, which improves the estimation of the treatment effect. It also combines results of studies that are contrasting, in a way that it weighs those. ${ }^{10}$ The objective of this study was to combine generated research data in a meta-analysis to provide a more precise estimate of the effect of 2 or 3 times daily milking sessions on the production of dairy cows.

\section{Materials and methods Literature search}

A literature search was performed in PubMed, Google Scholar, and Agricola-USDA, together with citations in reviews or scientific papers for a more comprehensive search. Selected studies had to meet the following criteria: 1) use of lactating dairy cows as experimental units; 2 ) report information on dry matter intake (DMI), milk production, and milk composition; 3 ) include contrasts between twice $(2 \times)$ and thrice (3x) daily milking sessions; and 4) report the standard error, or the standard deviation of the mean for the variables measured. A total of 21 publications were found, but only 14 met the previous criteria for conducting the meta-analysis. Three of the articles used in the meta-analysis were pen studies, and two used Jersey cows and reported two different trials (Table 1). Only a single study used lactating dairy cows on pasture ${ }^{30}$. The average trial duration was $220 \pm 102$ milking days. 
Table 1. Summary of papers used for a meta-analysis of production response of cows on $2 \times$ or $3 \times$ milking frequency.

\begin{tabular}{|c|c|c|c|c|c|c|}
\hline Author (s) and year & Trials & Cows & Breed & Trial duration (d) & Feeding system & Response variables \\
\hline Pearson et al. $(1979)^{21}$ & 1 & 26 & $\mathrm{H}$ & 182 & Individual & DMI, milk yield, yield of milk fat and protein \\
\hline Poole $(1982)^{22}$ & 1 & 58 & $\mathrm{H}$ & 210 & Individual & DMI, milk yield, percentage of milk fat \\
\hline Waterman et al. $(1983)^{23}$ & 2 & 48 & $\mathrm{H}_{1} \mathrm{~J}$ & 88 & Individual & Milk yield \\
\hline Amos et al. $(1985)^{24}$ & 1 & 47 & $\mathrm{H}$ & 301 & Individual & $\begin{array}{l}\text { DMI, milk yield, percentages of milk fat and } \\
\text { protein, yield of milk fat }\end{array}$ \\
\hline DePeters et al. $(1985)^{25}$ & 1 & 52 & $\mathrm{H}$ & 308 & Individual & $\begin{array}{l}\text { DMI, milk yield, percentages of milk fat and } \\
\text { protein, yield of milk fat and protein }\end{array}$ \\
\hline Allen et al. $(1986)^{5}$ & 1 & 14 & $\mathrm{H}$ & 305 & Pen & Milk yield, yield of milk fat \\
\hline Gisi et al. $(1986)^{26}$ & 1 & 56 & $\mathrm{H}$ & 305 & Individual & Milk yield, percentage of milk fat, yield of milk fat \\
\hline Barnes et al. $(1990)^{27}$ & 1 & 183 & $\mathrm{H}$ & 305 & Individual & $\begin{array}{l}\text { DMI, milk yield, percentages of milk fat, yield of } \\
\text { milk fat }\end{array}$ \\
\hline Economides $(1999)^{2}$ & 2 & 142 & $\mathrm{H}$ & 53 & Individual & $\begin{array}{l}\text { DMI, milk yield, percentages of milk fat and } \\
\text { protein }\end{array}$ \\
\hline Smith et al. $(2002)^{28}$ & 1 & 20044 & $\mathrm{H}$ & 305 & Pen & Milk yield, percentages of milk fat and yield \\
\hline McNamara et al. $(2008)^{29}$ & 1 & 42 & $\mathrm{H}$ & 42 & Individual & $\begin{array}{l}\text { DMI, milk yield, percentages of milk fat and } \\
\text { protein, yield of milk fat and protein }\end{array}$ \\
\hline Hart et al. $(2013)^{4}$ & 1 & 24 & $\mathrm{H}$ & 149 & Individual & $\begin{array}{l}\text { DMI, milk yield, percentages of milk fat and } \\
\text { protein, yield of milk fat and protein }\end{array}$ \\
\hline Phyn et al. (2014) $)^{30}$ & 1 & 62 & $\mathrm{H}, \mathrm{H} \times \mathrm{J}$ & 224 & Individual & $\begin{array}{l}\text { Milk yield, percentages of milk fat and protein, } \\
\text { yield of milk fat and protein }\end{array}$ \\
\hline Atashi $(2015)^{6}$ & 1 & 648 & $\mathrm{H}$ & 305 & Pen & Milk yield, yield of milk fat \\
\hline
\end{tabular}

DMI: dry matter intake; H: Holstein cows; J: Jersey cows. 
It has been reported that milk production response to frequent milking is more pronounced in primiparous than multiparous cows. ${ }^{11,12}$ In this meta-analysis, data from primiparous and multiparous cows were pooled, because of the impracticality of applying different milking frequencies in large commercial herds.

\section{Parameters and data extraction}

The parameters evaluated were DMI, milk production, and percentages and yields of milk fat and protein. The data set included mean, standard deviation, and number of cows per treatment group. Production parameters of the studies used in the meta-analysis averaged $21.40 \pm 4.84 \mathrm{~kg} / \mathrm{d}$ of DMI, $27.44 \pm 5.07 \mathrm{~kg} / \mathrm{d}$ milk yield, $3.71 \pm 0.34 \%$ milk fat, $1.01 \pm 0.19 \mathrm{~kg} / \mathrm{d}$ milk fat, $3.15 \pm 0.27 \%$ milk protein, and $0.93 \pm 0.16 \mathrm{~kg} / \mathrm{d}$ milk protein. The precision of the estimate was based on the standard deviation for treatment and control groups reported in the article. When the article did not provide the standard deviation, it was calculated by multiplying the standard error of the mean by the square root of the number of cows. Some studies did not report yields of milk fat and protein, and these were estimated from their percentages in milk. In this case, the standard error from their respective milk fat and protein percentages were used. This strategy was adopted to increase the amount of milk fat and protein yield data, which improved the power of the meta-analysis for these parameters.

\section{Statistical analyses}

The effects of milking frequency ( $2 x$ vs $3 x$ ) on the production responses of lactating dairy cows were evaluated through a meta-analysis using the fixed and random effects models with the R statistical software program (2015). ${ }^{13}$ The specific meta-analysis package Metafor was used. ${ }^{14}$ Each production parameter was first analysed by the fixed effects model to estimate the effect size (ES), 95\% confidence interval (Cl), and statistical significance of ES. Heterogeneity in experiment level ES was assessed with the Cochran's $Q$ statistic chi-square test, ${ }^{15}$ which reflects fundamental differences in study design and analytical methods, as well as statistical variation around the response. The analysis of the estimated ES was calculated by the standardised Z-statistic. If the $Q$ test was significant, a random effect model was used. ${ }^{16}$ The meta-analysis was adapted to a random-effect model since the $Q$ test indicated heterogeneity among ES for all variables $(P<0.05)$. The heterogeneity among studies was evaluated with the $\mathrm{I}^{2}$ statistic, ${ }^{17}$ which describes the percentage of total variation across studies due to heterogeneity, rather than chance. ${ }^{16} \mathrm{~A}$ value higher than $50 \%$ is considered substantial heterogeneity. ${ }^{18}$ For all production response outcomes, the weighted mean difference of $2 x$, relative to $3 \times$ milking, were calculated. Statistical significance was considered at $P \leq 0.05$.

The effects of milking frequency on the production response were displayed in forest plots, using the standardised mean difference (SMD) of each parameter according to the random-effect model. Information presented in forest plots also provided the means and $95 \% \mathrm{Cl}$ for primary studies. The weight of each study is calculated by the inverse of the variance of the ES. The SMD shows the difference across studies as an index, and is calculated by dividing the mean difference in each study by the standard deviation of one or both opulations. ${ }^{16}$ The SMD of each 
production response parameter between $2 \times$ and $3 \times$ was the outcome of interest displayed in the forest plot. The presence of publication bias was investigated using funnel plots, which is a simple scatterplot of the treatment effects estimated from individual studies (horizontal axis) against a measure of study size (vertical axis 19), and the Begg's test. ${ }^{20}$

Meta-regression analysis was used to explore any other source of undetected heterogeneity and to provide greater insight and a more unambiguous interpretation of how study outcomes are not affected by factors other than milking frequency. The variables for meta-regression were year of publication, trial duration, and breed.

\section{Results}

Meta-regression analysis demonstrated that the year of publication, the trial duration, and cattle breed did not contribute to the heterogeneity of milk production parameters ( $P>0.05$; Table 2).

Estimates for the differences in production parameters (effect size estimates) for cows milked either $2 x$ or $3 x$ are shown in Table 3 . Daily milk production $(E S=-0.510 ; P \leq 0.0001)$, milk fat yield $(E S=-0.026)$, and milk protein production ( $E S=-0.310 ; P=0.04$ ) was lower $2.23,0.06$, and $0.05 \mathrm{~kg} / \mathrm{d}$, respectively, for cows milked $2 \times$. However, milk fat percentage ( $E S=0.329 ; P=0.0004)$ was 0.07 $\mathrm{kg} / \mathrm{d}$ higher in $2 \times$ milking frequency. No effects were found for $\mathrm{DMI}$ ( $E S=0.064$; $P=0.709)$ and milk protein percentage $(E S=0.026 ; P=0.460)$. Heterogeneity in the results among publications ( ${ }^{2}$ statistic) was moderate for milk fat percentage $\left(\mathrm{I}^{2}=48 \%\right)$, and high $\left(\mathrm{I}^{2}>50 \%\right)$ for DMI, milk production, milk fat yield, and milk protein yield. No heterogeneity was observed for milk protein percentage $\left(\mathrm{I}^{2}=0 \%\right)$. Meta-analysis of multiple studies produce a more precise estimate of the negative (diamond to the left of the dotted line) or positive (diamond to the right) response to milking frequency, and are shown in forest plots (Figures 1 and 2). No significant publication bias was found for the parameters analysed (Figure 3; Begg's test; $P>0.05)$. However, a trend $(P=0.071)$ in publication bias was observed for milk fat percentage. Funnel plots of the effect of milking frequency on production response parameters for assessing publication bias are in Figure 3. Funnel plots showed almost an equal number of studies on every side of the overall ES estimate for DMI, milk production, and percentage and yield of milk fat and protein, which supports the inference that no publication bias existed among studies.

\section{Discussion}

High producing dairy cows in early lactation are most of the time in negative energy balance. During the transition period, they also have reduced appetites which further challenges their ability to fulfil their nutrient requirements. When milking goes from $2 x$ to $3 x$, the sudden increased yield is not immediately accompanied by a parallel higher nutrient uptake which further challenges this balance. The severity of this discrepancy depends on the cow's genetic potential for milk production, the adequacy of the diet, feed and herd management practices, and the environ- 
Table 2. Estimated effect of year of publication, duration of the trial and cattle breed on the effect of milking frequency on dry matter intake, milk yield, milk and protein percentage and yield.

\begin{tabular}{|c|c|c|c|}
\hline Variable & Coefficient & $\begin{array}{c}\text { Coefficient } \\
95 \% \mathrm{Cl}\end{array}$ & P-value \\
\hline \multicolumn{4}{|l|}{ DMI (kg/d) } \\
\hline Intercept & 1.706 & {$[0.712 ; 2.700]$} & 0.230 \\
\hline Year & -0.190 & {$[-0.332 ;-0.048]$} & 0.333 \\
\hline Trial duration & -0.005 & {$[-0.008 ;-0.002]$} & 0.135 \\
\hline \multicolumn{4}{|c|}{ Milk yield (kg/d) } \\
\hline Intercept & -2.144 & {$[-6.215 ; 1.928]$} & 0.302 \\
\hline Year & 0.105 & {$[-0.107 ; 0.317]$} & 0.330 \\
\hline Trial duration & -0.007 & {$[-0.017 ; 0.002]$} & 0.132 \\
\hline Breed & 0.558 & {$[-1.559 ; 2.676]$} & 0.606 \\
\hline \multicolumn{4}{|l|}{ Milk fat (\%) } \\
\hline Intercept & 0.092 & {$[-0.140 ; 0.324]$} & 0.437 \\
\hline Year & -0.002 & {$[-0.031 ; 0.027]$} & 0.911 \\
\hline Trial duration & -0.000 & {$[-0.0007 ; 0.0007]$} & 0.988 \\
\hline Breed & -0.002 & {$[-0.236 ; 0.231]$} & 0.985 \\
\hline \multicolumn{4}{|c|}{ Fat yield (kg/d) } \\
\hline Intercept & -0.662 & {$[-1.452 ; 0.128]$} & 0.100 \\
\hline Year & 0.052 & {$[0.005 ; 0.098]$} & 0.129 \\
\hline Trial duration & -0.001 & {$[-0.003 ; 0.0003]$} & 0.126 \\
\hline Breed & 0.378 & {$[-0.266 ; 1.022]$} & 0.250 \\
\hline \multicolumn{4}{|l|}{ Milk protein (\%) } \\
\hline Intercept & -0.121 & {$[-0.289 ; 0.047]$} & 0.157 \\
\hline Year & 0.009 & {$[-0.021 ; 0.038]$} & 0.556 \\
\hline Trial duration & 0.0002 & {$[-0.0003 ; 0.0006]$} & 0.452 \\
\hline Breed & 0.060 & {$[-0.148 ; 0.268]$} & 0.578 \\
\hline \multicolumn{4}{|c|}{ Protein yield (kg/d) } \\
\hline Intercept & -0.035 & {$[-0.265 ; 0.195]$} & 0.767 \\
\hline Year & -0.003 & {$[-0.027 ; 0.022]$} & 0.816 \\
\hline Trial duration & -0.0004 & {$[-0.001 ; 0.0002]$} & 0.146 \\
\hline Breed & 0.063 & {$[-0.161 ; 0.288]$} & 0.581 \\
\hline
\end{tabular}

$\mathrm{Cl}=$ confidence interval. 
Table 3. Summary of effect size estimates on production response of dairy cows on $2 \times$ vs $3 \times$ milking frequency.

\begin{tabular}{|c|c|c|c|c|c|c|}
\hline \multirow{2}{*}{$\begin{array}{l}\text { Outcome measured (difference } \\
\text { between } 2 \times \text { and } 3 \times \text { milking } \\
\text { frequency) }\end{array}$} & \multirow{2}{*}{$\begin{array}{l}\text { Weighted mean difference } \\
\text { for } 2 \times-3 \times \text { milking frequency }{ }^{a} \\
{[95 \% \mathrm{Cl}]}\end{array}$} & \multirow{2}{*}{ Effect size [95\% Cl] } & \multirow{2}{*}{$\begin{array}{c}1^{2} \\
(\%)\end{array}$} & \multirow{2}{*}{$\begin{array}{l}\text { P-value for } \\
\text { effect size }\end{array}$} & \multicolumn{2}{|c|}{$\begin{array}{c}\text { Number of records/ } \\
\text { treatment }\end{array}$} \\
\hline & & & & & $2 x^{b}$ & $3 x^{b}$ \\
\hline DMI (kg/d) & $-0.11[-1.29 ; 1.07]$ & $0.064[-0.271 ; 0.398]$ & 59.4 & 0.709 & 288 & 286 \\
\hline Milk production (kg/d) & $-2.23[-3.15 ;-1.30]$ & $-0.510[-0.739 ;-0.282]$ & 69.0 & $<0.0001$ & 10540 & 10906 \\
\hline Milk fat (\%) & $0.07[0.03 ; 0.11]$ & $0.329[0.146 ; 0.512]$ & 47.6 & 0.0004 & 10172 & 10538 \\
\hline Milk fat yield (kg/d) & $-0.06[-0.15 ; 0.03]$ & $-0.223[-0.422 ;-0.024]$ & 60.5 & 0.028 & 10516 & 10882 \\
\hline Milk protein (\%) & $0.001[-0.02 ; 0.02]$ & $0.026[-0.043 ; 0.097]$ & 0.0 & 0.460 & 10022 & 10391 \\
\hline Milk protein yield (kg/d) & $-0.05[-0.08,-0.02]$ & $-0.310[-0.615,-0.004]$ & 71.3 & 0.047 & 10035 & 10882 \\
\hline
\end{tabular}

a Difference between cows milked $2 x$ and $3 \times$, weighted by the precision of the study.

b Milking frequency: $2 x=$ two times per day, $3 x=$ three times per day.

$1^{2}$ measure de proportion of variability that is explained by differences between the included studies rather than by sampling error in the meta-analysis.

$\mathrm{Cl}$ : confidence interval. 
Item

\section{Forest plot}

\section{$\operatorname{DMl}(\mathrm{kg} / \mathrm{cow} / \mathrm{d})$}

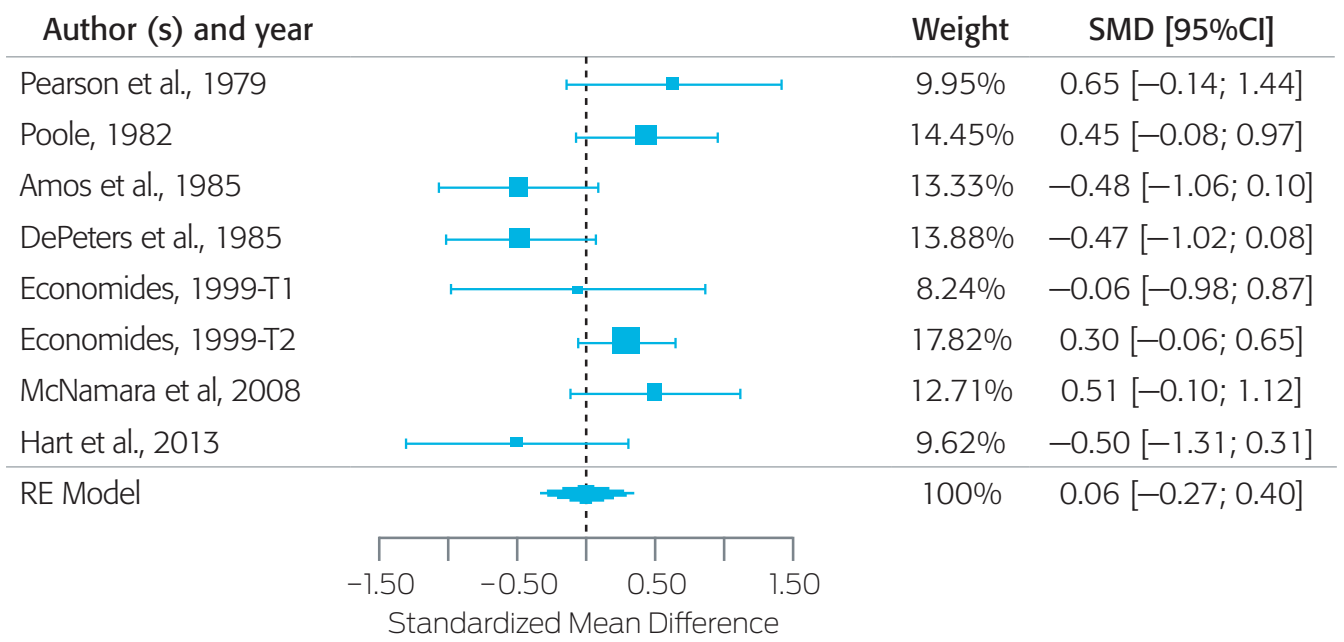

Milk production (kg/cow/d)

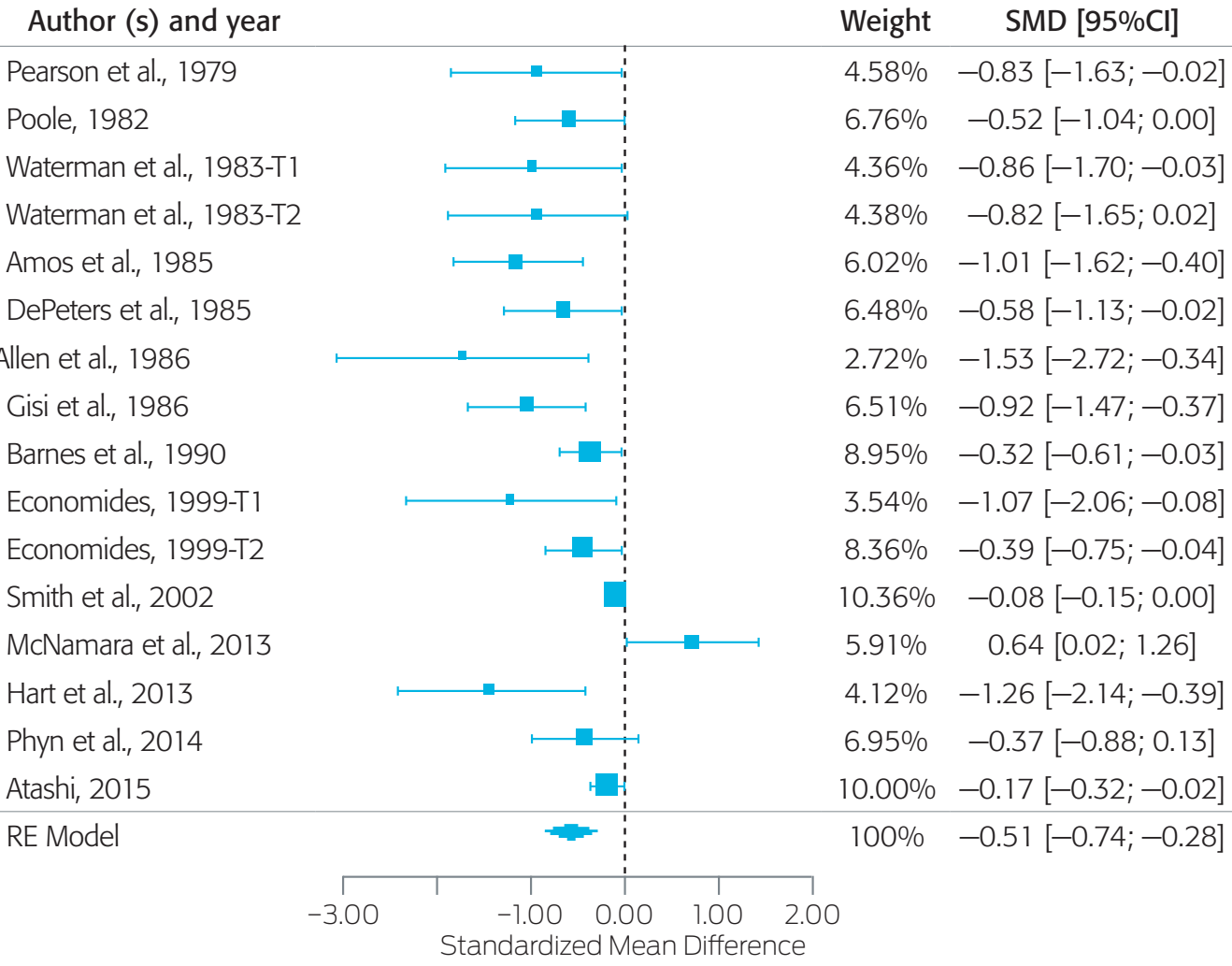

Figure 1. Forest plot of the effect of milking frequency on dry matter intake (DMI) and milk yield production in dairy cows. The $x$-axis shows the z-statistic- standardised mean difference (SMD). The length of the horizontal lines represents the $95 \% \mathrm{Cl}$ for the SMD of milking frequency on milk variables from each study. The size of the square in the center is proportional to the weight assigned to the study, and specific values in percentage are listed in the following column. The vertical dotted line represents a mean difference of 0 or no effect. Points to the left of the dotted line represent a decrease in the measured variable, whereas points to the right indicate an increase. The diamond at the bottom represents the effect of $2 \times$ vs $3 \times$ milking frequency on DMI and milk production. 
Item

\section{Forest plot}

Milk fat (\%)

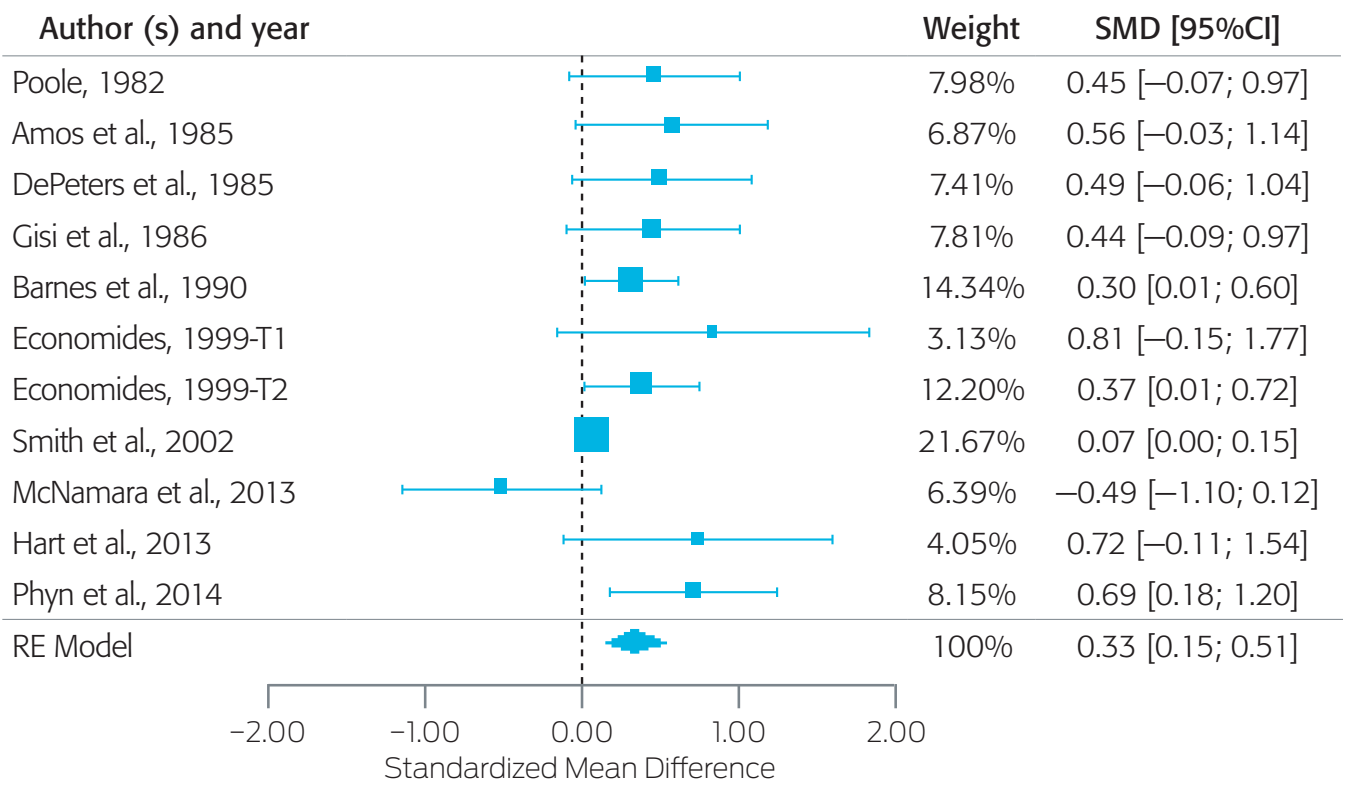

Author (s) and year

Pearson et al., 1979

Poole, 1982

Amos et al., 1985

DePeters et al., 1985

Allen et al., 1986

Gisi et al., 1986

Barnes et al., 1990

Economides, 1999-T1

Economides, 1999-T2

Smith et al., 2002

McNamara et al, 2008

Phyn et al., 2014

Atashi, 2015

RE Model
Weight SMD [95\%Cl]

$4.43 \%-0.65[-1.43 ; 0.14]$

$7.37 \%-0.05[-0.56 ; 0.47]$

$6.44 \%-0.61[-1.19 ;-0.02]$

$6.86 \%-0.49[-1.04 ; 0.06]$

$2.38 \%-1.47[-2.65 ;-0.29]$

$7.03 \%-0.69[-1.23 ;-0.15]$

$11.08 \%-0.30[-0.59 ;-0.01]$

$3.21 \%-1.01[-1.99 ;-0.03]$

9.99\% -0.02 [-0.37;0.33]

$14.24 \%-0.07[-0.14 ; 0.00]$

$6.09 \% \quad 0.52[-0.10 ; 1.13]$

$7.54 \% \quad 0.39[-0.11 ; 0.90]$

$13.36 \%-0.14[-0.29 ; 0.02]$

Figure 2. 
Item

\section{Forest plot}

\section{Milk protein (\%)}

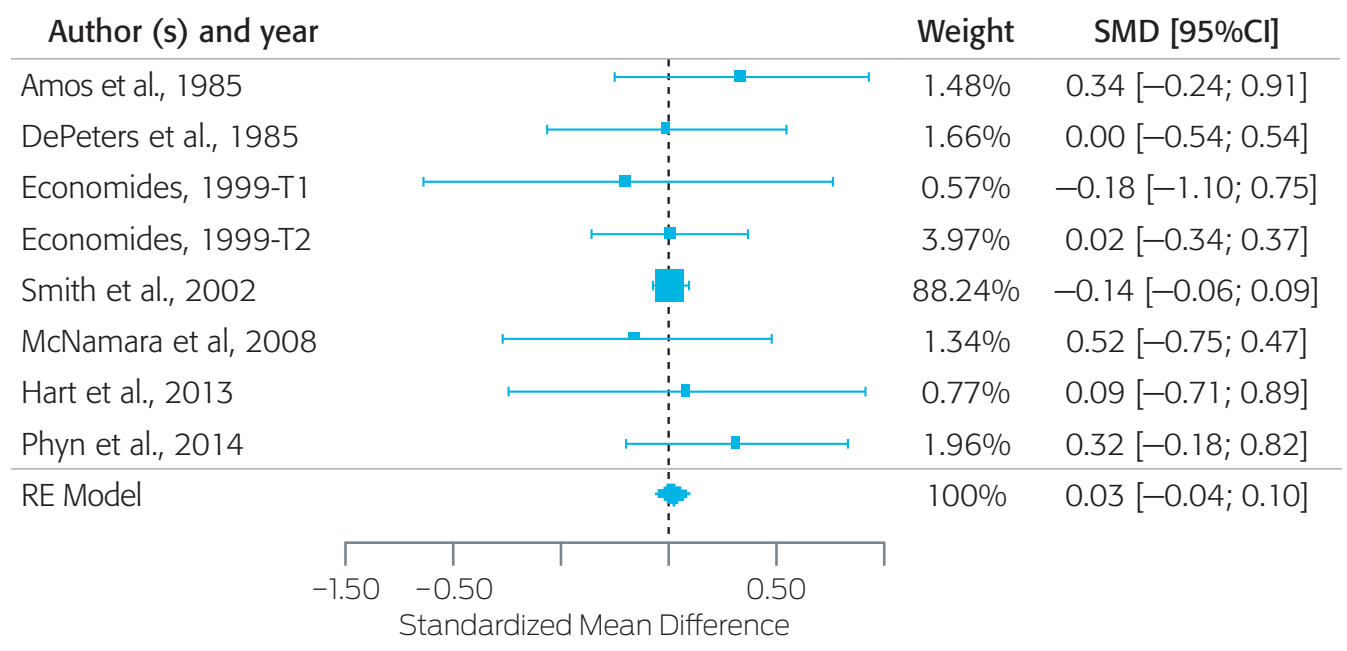

\section{Milk protein yield $(\mathrm{kg} / \mathrm{cow} / \mathrm{d})$}

\begin{tabular}{|c|c|c|c|}
\hline Author (s) and year & & Weight & SMD $[95 \% \mathrm{Cl}]$ \\
\hline Pearson et al., 1979 & $\longmapsto$ & $8.25 \%$ & $-0.65[-1.43 ; 0.14]$ \\
\hline Amos et al., 1985 & $\longmapsto$ & $10.95 \%$ & $-0.61[-1.20 ;-0.03]$ \\
\hline DePeters et al., 1985 & $\longrightarrow$ & $11.44 \%$ & $-0.55[-1.10 ; 0.01]$ \\
\hline Economides, 1999-T1 & & $6.35 \%$ & $-1.00[-1.98 ;-0.02]$ \\
\hline Economides, 1999-T2 & 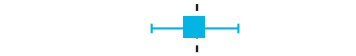 & $14.73 \%$ & $-0.02[-037 ; 0.33]$ \\
\hline Smith et al., 2002 & 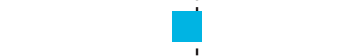 & $18.12 \%$ & $-0.07[-0.15 ; 0.00]$ \\
\hline McNamara et al., 2013 & $\rightarrow$ & $10.51 \%$ & $0.53[-0.09 ; 1.14]$ \\
\hline Hart et al., 2013 & $\longrightarrow$ & $7.33 \%$ & $-1.24[-2.12 ; 0.37]$ \\
\hline Phyn et al., 2014 & $\longmapsto$ & $12.31 \%$ & $-0.09[-0.59 ; 0.41]$ \\
\hline RE Model & $=-1$ & $100 \%$ & $0.31[-0.61 ; 0.00]$ \\
\hline-3.00 & \begin{tabular}{cc|} 
& \\
0.00 & 1.00
\end{tabular} & 2.00 & \\
\hline
\end{tabular}

Figure 2. Forest plot of the effect of milking frequency on components percentage and yield in dairy cows. The x-axis shows the z-statistic- standardised mean difference (SMD). The length of the horizontal lines represents the $95 \% \mathrm{Cl}$ for the SMD of milking frequency on milk variables from each study. The size of the square in the center is proportional to the weight assigned to the study, and specific values in percentage are listed in the following column. The vertical dotted line represents a mean difference of 0 or no effect. Points to the left of the dotted line represent a decrease in the measured variable, whereas points to the right indicate an increase. The diamond at the bottom represents the overall effect of $2 x$ vs $3 \times$ milking frequency on milk components percentage and yield. 


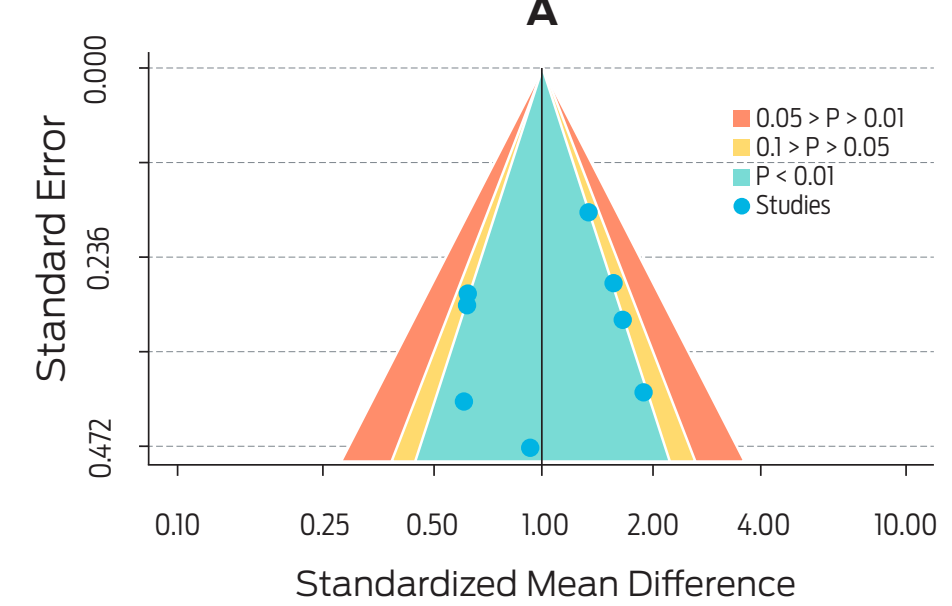

D

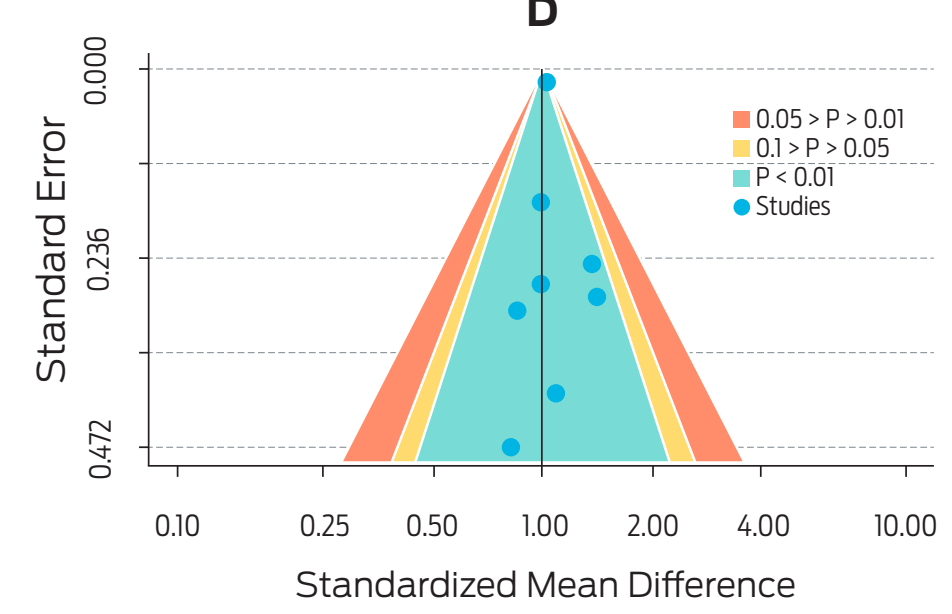

B

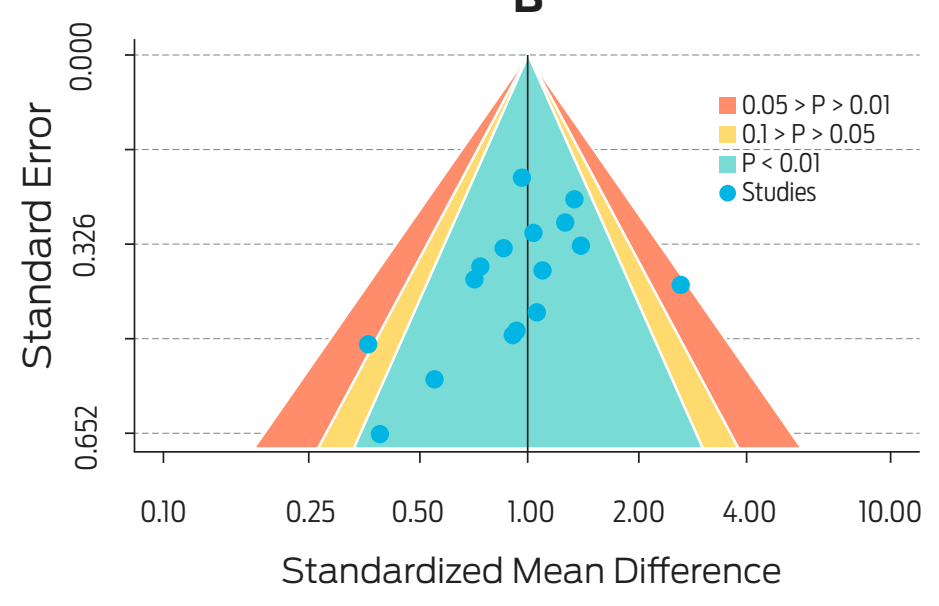

$\mathbf{E}$

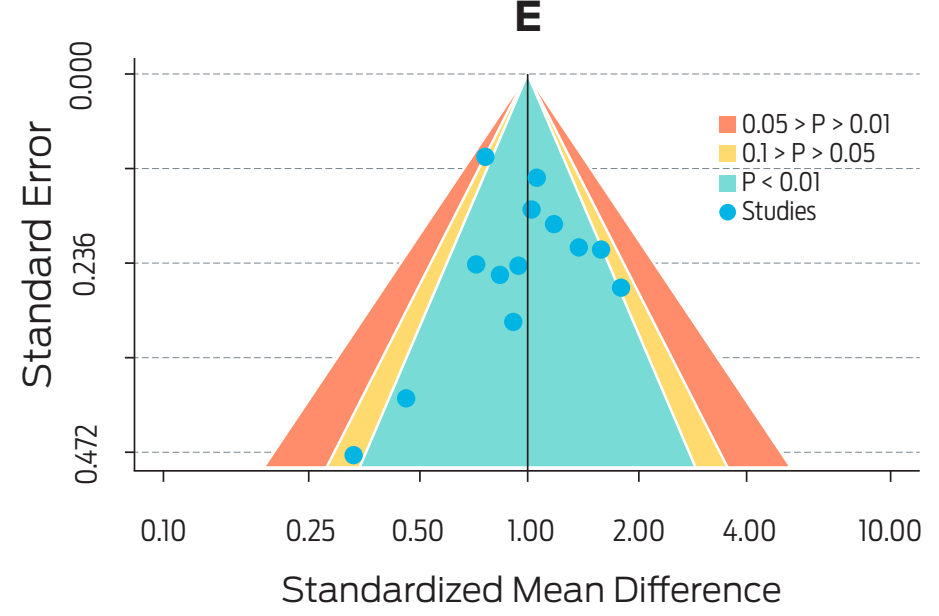

C

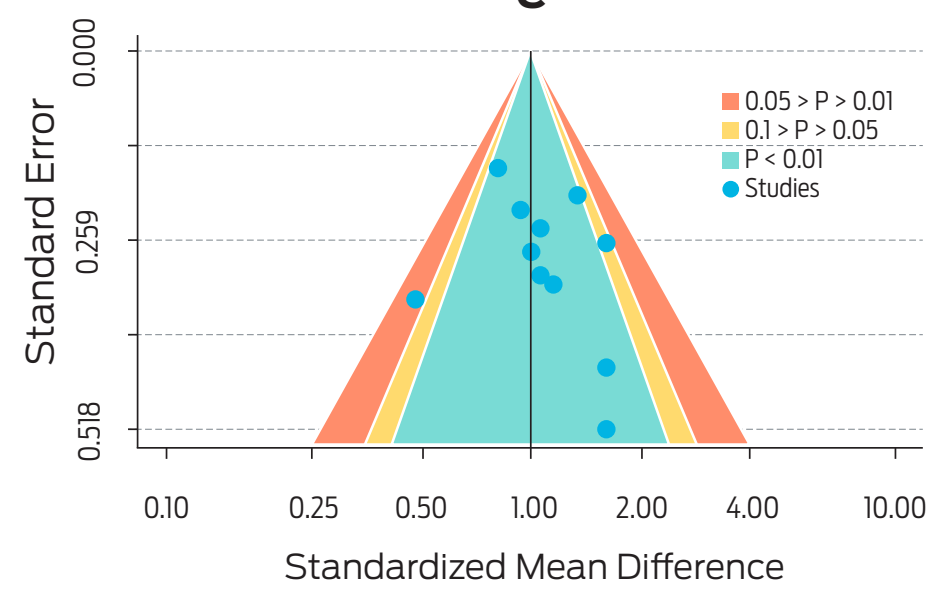

$\mathbf{F}$

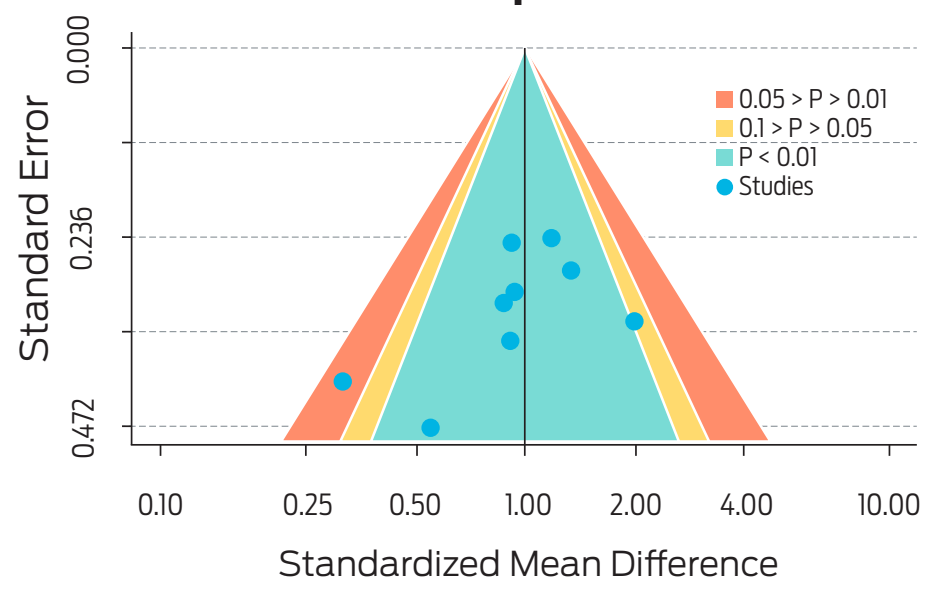

Figure 3. Funnel plots of the effect of milking frequency on $D M I(A ; P=0.557)$, milk production $(B ; P=0.167)$, milk fat percentage $(C ; P=0.071)$, milk fat yield ( $D$; $\mathrm{P}=0.861)$, milk protein percentage $(\mathrm{E} ; \mathrm{P}=0.507)$, and milk protein yield $(\mathrm{F} ; \mathrm{P}=0.587)$. The $\mathrm{x}$-axis shows the standardised mean difference, and the $y$-axis shows its standard error. The vertical lines represent the overall effect size (ES) estimate. The diagonal lines indicate an estimate of the $95 \% \mathrm{Cl}$ of the ES estimate. An almost equal number of studies was found on every side of the overall ES estimate, implying no publication bias between studies. Begg's test significance is in the parenthesis. 
ment. Higher milking frequencies in early lactation, lead to metabolism changes in response to the increased nutrient demand. ${ }^{31}$ These metabolic changes seem to be dependent not only on the expanded frequency but also on the length of time under the new frequency. If the additional milking is done only up to 21-30 days post-calving, then there are little metabolic changes in response to it. ${ }^{29}$ This needs to be taken into consideration when designing experiments to evaluate metabolic changes between different frequencies. Three distinct adaptation phases have been proposed through which the mammary gland adapts to increased or decreased milking frequency. ${ }^{32} \mathrm{~A}$ first one or acute phase (one to several days), a second one or medium-term phase (days to weeks), and a third one a long-term phase (weeks to months). The first phase is characterised by acute regulatory mechanisms such as feedback inhibition of lactation, leakiness, and the onset of apoptosis. During the second phase, the gland adapts to a state of lower or higher cellular activity (e.g., enzyme activity) and that results in limited metabolic changes. ${ }^{29}$ The longterm phase results in changes in the mammary parenchyma resulting in changes in cell numbers.

One of the most apparent effects as a result of the increased milking frequency is the mobilisation of body reserves. Research has shown that fat mobilisation is the primary mechanism by which this is accomplished. Higher plasma NEFA and BHBA concentrations, together with losses in BCS are typical as a result of increased milking frequency. ${ }^{33}$ The later was confirmed by observing reduced BCS, in cows milked $6 \times$ when compared to $3 \times .^{34}$ The opposite is also true since decreasing milking frequency improves energy balance, as demonstrated in cows milked $1 \times$ with reduced BCS loss, and reduced BW loss during early. ${ }^{29}$ The metabolic changes that result from the stimulation that happens as a result of additional milkings are complex. They depend on the coordination of nutrient and hormone peripheral signals, with local regulatory mechanisms that adjust rates of nutrients availability to match mammary epithelial cells synthetic capacity. ${ }^{35}$ Plasma growth hormone and insulin-like growth factor type I (IGF-I) concentrations, were elevated in cows milked six times daily; prolactin and oxytocin also increased, but insulin decreased. ${ }^{36}$ Post-treatment differences persisted only for insulin and IGF-I. Increased frequency of udder emptying increased milk production and was associated with elevated growth hormone, IGF-I, prolactin, and oxytocin. Similarly, increases in enzyme activity, lactose synthesis, and DNA in the alveolar tissue of the mammary gland have been observed when cows are milked more frequently. ${ }^{37}$ Meanwhile, the rise of milk production and changes in milk composition with more frequent milking intervals are regulated by local factors within the mammary gland, rather than other physiological mechanisms. ${ }^{7}$

This has been proven by a few experiments in which the treatment (e.g., $1 \times$ or $3 x$ ) was applied to two quarters on the same side of the udder, and the other contralateral half was milked $2 x$ as the control. Since the treatments are applied to the same cow, both halves of the udder are under the same environmental and management factors except the milking frequency. Hence, any treatment difference must be solely due to intramammary factors. The intramammary effects of milking frequency on milk yield have ranged from $-38 \%$ with $1 \times$ to $+32 \%$ with more frequent milking regimens. ${ }^{38}$

The papers of the present meta-analysis were strictly confined to those that reported DMI, milk production, and milk composition. This selection was an attempt 
to identify better the effect of increasing milking frequency on milk production ruling out the interference of stage of lactation, feeding system, type and quality of the diets, and lactation number.

Even though milking thrice-daily was proposed since 1920, it is not widely implemented in dairy farms, probably because the variability in production responses, which range between 9 to 39\%. ${ }^{39}$ Benefits of the use of meta-analysis is that multiple studies can be integrated, resolving contradictions among different research, and offer critical insights into the current state of knowledge. ${ }^{40,41}$ The value of the present meta-analysis is that the positive effect of $3 \times$ milking was confirmed for milk production and yields of milk protein and milk fat, without increasing DMI.

With thrice-milking higher milk production is expected to promote an increase in dry matter intake because of energy demands; however, cows milked $3 \times$ did not consume more feed. ${ }^{27}$ Only when milk frequency increased up to $6 x$, a rise on DMI was observed. ${ }^{43}$ This was confirmed in earlier research ${ }^{25}$ where Holstein first lactation cows during a full lactation (44 week) milked twice and three times a day. When older cows were switched from 2 to $3 \times$ they produced $17 \%$ more milk over the entire lactation than cows on $2 x$ daily. Dry matter and energy intakes were not affected by three times milking, but gain of body weight was reduced. Cows milked $3 \times$ during their first lactation produced $6 \%$ more milk than the $2 \times$ controls. Dry matter and energy intakes were not affected by $3 \times$ milking, but did affect first lactation cows with reduced weight gains over the lactation. No changes in DMI were also reported more recently for cows milked $2 \times$ vs $3 \times$. In a large and prolonged experiment, ${ }^{27}$ Holstein cows were milked twice or thrice daily beginning at calving. Cows yielded approximately 25 and 30\% more milk during first and second lactation, respectively, than control cows. Cows milked $3 \times$ daily had decreased milk fat percentage and tended to weigh less, suggesting more body tissue was catabolised for milk production, though DMI did not differ from that of cows milked $2 \times$.

Therefore, the present meta-analysis confirms that increasing milking frequency did not affect DMI. Nonetheless, we cannot discard that the lack of effect is not related to the moderate heterogeneity observed for DMI in the present study $\left(I^{2}=59 \%\right)$. One additional explanation is that the metabolic changes that will lead to changes in feed intake depend in the milking frequency, but also on the duration of the new frequency. ${ }^{29}$ The lack of effect of $3 \times$ milking frequency on DMI could be explained if we recall that milk production increase to more frequent milking is mostly due to local regulation at the mammary gland. 37,38,42 Indeed, milk yield depends on the number and activity of secretory cells, and increasing the milking frequency reduces the alveoli epithelial cell apoptosis ${ }^{43}$ and improves enzyme activity and DNA synthesis, making milk production more efficient without the requirement of additional nutrients. ${ }^{37,38,44}$ These effects are mediated by several galactopoietic hormones like growth hormone, insulin-like growth factor I, oxytocin, and prolactin which blood concentrations are increased in cows that are milked more frequently. ${ }^{37}$ Specifically, an increase in prolactin secretion and its receptor with $3 \times$ milking has been observed. ${ }^{45}$ Prolactin is essential for the regulation of milk synthesis at the local level as it stimulates lactose synthesis (the primary regulator of milk volume) and has a proliferative effect on mammary gland cells. ${ }^{46}$ Additionally, prolactin reduces the leakiness of the tight junctions of mammary gland epithelial cells. ${ }^{38}$ This leakiness increases mammary gland pressure and loss of epithelial cells function that reduce milk secretion. ${ }^{7}$ 
As milk fat and protein yields are variables calculated from milk production and milk components percentage, the positive effect of milking frequency on these variables in the present meta-analysis is mostly attributable to the increase in milk volume related to lactose synthesis. Mammary gland ability to extract nutrients is not different between cows milked $2 \times$ or $3 \times$, and only an increase in glucose-1-phosphate has been reported when cows are milked thrice per day. ${ }^{47}$ Therefore, the increase in lactose synthesis could be related to the upregulation of the phosphoglucomutase enzyme that catalyses the synthesis of glucose-1-phosphate as part of the galactose production pathway. 47,48

An increase of $2.23 \mathrm{~kg}$ per day in milk production without an increase in DMI is highly desirable, since it would result in approximately $468 \mathrm{~kg}$ additional milk over a 210-day lactation. Assuming milk prices at close to $M X \$ 6.11,49$ this could result in an additional MX $\$ 2,859$ to the producer. It is important however to balance this extra income with the necessary management changes that assure adequate feed bunk management, adding milking shift, and improved milking management to guarantee udder health. ${ }^{39}$ An economic analysis demonstrated that it is more feasible switching to $3 \times$ when cows in $2 \times$ milking produce more than $24.5 \mathrm{~kg}$ of milk per day. ${ }^{50}$

Factors such as body condition score, health, reproduction, and economic impact were not included in this meta-analysis, and the authors recommend their study in future research. It has been reported that cows on $1 X$ experienced less negative energy balance than cows on $2 x$ and $3 x$; however, without a negative effect on reproduction. ${ }^{29}$ Also, cows on $3 \times$ were prone to increased lameness (36\%) when compared to $2 \times .{ }^{51}$

\section{Conclusions and implications}

Increasing milking frequency from $2 x$ to $3 x$ has a positive effect on milk production and yields of milk fat and milk protein without increasing DMI. The application of $3 \times$ milking frequency must consider dairy cow management, labor availability, and milking parlour infrastructure particular to each dairy farm. While the economic results may not justify $3 \times$ milking for the entire herd, it certainly could be considered for pens of cows more likely to respond. Future research should consider the energy balance of the cows, animal health, breed and the economic viability when implemented $3 \times$ milking frequency in lactating dairy cows. 


\section{Conflicts of interest}

The authors confirm that there are no conflicts of interest associated with this publication.

\section{Author contributions}

Á. G. and K. R. H. contributed to building the structure of the article; D. G. R. S., H. G. S., E. O. M. and A. R. G. contributed to search and criticize the articles included in the meta-analysis; J. I. S. D. carried out the statistical analysis.

\section{References}

1. Erdman RA, Varner M. Fixed yield responses to increased milking frequency. J Dairy Sci. 1995;78:1 199-203.

2. Economides S. The effects of milking cows three times daily on milk yield, milk composition, and profitability compared to two times daily milking. Report. Agricultural Research Institute Ministry of Agriculture, Natural Resources and the Environment. 1999;3-12.

3. Sirohi AS, Pandey HN, Singla M. Effects of milking frequency on feed intake, body weight and haemato-biochemical changes in crossbred cows. J App Anim Res. 2012;40:63-8.

4. Hart KD, McBride BW, Duffield TF, DeVries TJ. Effect of milking frequency on behavior and productivity of lactating dairy cows. J Dairy Sci. 2013;96:6973-85.

5. Allen DB, DePeters EJ, Laben RC. Three times a day milking: effects on milk production, reproductive efficiency, and udder health. J Dairy Sci. 1986;69:1441-6.

6. Atashi $\mathrm{H}$. Effect of milking frequency on the lactation performance and lactation curve of Holstein dairy cows in Iran. Iranian J Appl Anim Sci. 2015;5:273-8.

7. Wall EH, McFadden TB. Use it or lose it: Enhancing milk production efficiency by frequent milking of dairy cows. J Anim Sci. 2008;86 Suppl 1:27-36.

8. Greco T, Zangrillo A, Biondi-Zoccai G, London G. Meta-analysis: pitfalls and hints. Heart Lung Vessel. 2013;5:219-25.

9. Biondi-Zoccai $G$, Landoni $G$, Modena MG. A journey into clinical evidence: from case reports to mixed treatment comparisons. HSR Proc Intensive Care Cardiovasc Anesth. 2011;3:93-6.

10. Ilic I. Meta-analysis. Acta Med Med. 2009;48:28-31.

11. Copeland L. Milk and butterfat yields of Jersey cows as affected by frequency of milking. J Dairy Sci. 1934;17:815-21.

12. Lush JL, Shrode RR. Changes in milk production with age and milking frequency. J Dairy Sci. 1953;33:338-57.

13. R Core Team. A language and environment for statistical computing. R. Foundation for Statistical Computing, Vienna, Austria. 2015. Available at: https:// www.R-project.org

14. Viechtbauer W. Conducting meta-analyses in R with the Metafor package. J Stat Software. 2010;36:1-48. Available at: http://www.jstatsoft.org/v36/i03/

15. Egger $M$, Smith $G D$, Altman D. Systematic reviews in health care. Meta-analysis in context. London: BMJ Publishing Group; 2001.

16. Lean IJ, Rabiee AR, Duffield TF, Dohoo IR. Invited review: Use of meta-analysis in animal health and reproduction: Methods and applications. J Dairy Sci. 2009;92:3545-65. 
17. Higgins JPT, Thompson SG, Deeks JJ, Altman DG. Measuring inconsistencies in meta-analyses. BMJ. 2003;327:557-60.

18. Higgins JPT, Thompson SG. Quantifying heterogeneity in a meta-analysis. Stat Med. 2002;21:1539-58.

19. Sterne JA, Harbord RM. Funnel plots in meta-analysis. Stata J. 2004;4:127-41.

20. Begg CB, Mazumdar M. Operating characteristics of a rank correlation test for publication bias. Biometrics 1994;50:1088-101.

21. Pearson RE, Fulton LA, Thompson PD, Smith JW. Three times a day milking during the first half of lactation. J Dairy Sci. 1979;62:1941-50.

22. Poole D. The effects of milking cows three times daily. Animal Science, 1982;34:197-201. doi:10.1017/S0003356100000672

23. Waterman DF, Harmon RJ, Hemken RW, Langlois BE. Milking frequency as related to udder health and milk production. J Dairy Sci. 1983;66:253-8.

24. Amos HE, Kisier T, Loewenstein M. Influence of milking frequency on productive and reproductive efficiencies of dairy cows. J Dairy Sci. 1985;68:732-9.

25. DePeters EJ, Smith NE, Acedo-Rico J. Three or two times daily milking of older cows and first lactation cows for entire lactations. J Dairy Sci. 1985;68:123-32.

26. Gisi DD, DePeters EJ, Pelissier CL. Three times daily milking of cows in California dairy herds. J Dairy Sci. 1986;69:863-8.

27. Barnes MA, Pearson RE, Lukes-Wilson AJ. Effects of milking frequency and selection for milk yield on productive efficiency of Holstein cows. J Dairy Sci. 1990;73:1603-11.

28. Smith JW, Ely LO, Graves WM, Gilson WD. Effect of milking frequency on DHI performance measures. J Dairy Sci. 2002;85:3526-33.

29. McNamara S, Murphy JJ, O'Mara FP, Rath M, Mee JF. Effect of milking frequency in early lactation on energy metabolism, milk production, and reproductive performance of dairy cows. Livest Sci. 2008;117:70-8.

30. Phyn CVC, Kay JK, Rius AG, Morgan SR, Roach CG, Grala TM, et al. Temporary alterations to postpartum milking frequency affect whole-lactation milk production and the energy status of pasture-grazed dairy cows. J Dairy Sci. 2014;97:6850-68.

31. Andersen JB, Friggens NC, Larsen $T$, Vestergaard M, Ingvartsen KL. Effect of energy density in the diet and milking frequency on plasma metabolites and hormones in early lactation dairy cows. J Vet Med. A Physiol Pathol Clin Med. 2004;51:52-7.

32. Knight $\mathrm{CH}$, Wilde $\mathrm{CJ}$, Peaker M. Manipulation of milk secretion. In: Garnsworthy PC, editor. Nutrition and lactation in the dairy cow. Tiptree: Anchor-Brendon; 1988. p. 3-14.

33. Soberon F, Lukas JL, Van Amburgh ME, Capuco AV, Galton DM, Overton TR. Effects of increased milking frequency on metabolism and mammary cell proliferation in Holstein dairy cows. J Dairy Sci. 2010;93:565-73.

34. Roche JR, Dillon PG, Stockdale CR, Baumgard LH, Van Baale JM. Relationships among international body condition scoring systems. J Dairy Sci. 2004;87:3076-9.

35. Bequette BJ, Douglass LW. The frequency of unilateral milking alters leucine metabolism and amino acid removal by the mammary gland of lactating goats. J Dairy Sci. 93:162-9. 
36. Bar-Pelled U, Maltz E, Bruckental I, Robinson B, Voet H, Tagari H. Relationship between frequent milking in early lactation and milk production of high producing dairy cows. J Dairy Sci. 1995;78:2726-36.

37. Hillerton JE, Knight $\mathrm{CH}$, Turvey A, Wheatley SD, Wilde CJ. Milk yield and mammary function in dairy cows milked four times daily. J Dairy Res. 1990; 57:285-94.

38. Stelwagen $\mathrm{K}$. Effect of Milking Frequency on mammary functioning and shape of the lactation curve. J Dairy Sci. 2001;84 E Suppl: E204-E211.

39. Armstrong DV. Milking frequency. Proceedings of the Western Dairy Management Conference, Las Vegas, Nevada. March 13-15, 1997. p. 79-84.

40. Glass GV. Primary, secondary, and meta-analysis of research. Educational Researcher. 1976;5:3-8.

41. Mikolajewicz N, Komarova SV. Meta-analytic methodology for basic research: A practical guide. Front Physiol. 2019;10:203.

42. Singh $K$, Erdman RA, Swanson KM, Molenaar AJ, Maqbool NJ, Wheeler TT, Arias JA, Quinn-Walsh EC, Stelwagen K. Epigenetic regulation of milk production in dairy cows. J Mammary Gland Biol Neoplasia. 2010;15:101-12.

43. Capuco AV, Ellis SE. Mammary gland development and homeostasis. Annu Rev Anim Biosci. 2013;1:179-202.

44. Wilde CJ, Henderson AJ, Knight CH, Blatchford DR, Faulkner A, Vernon RG. Effects of long-term thrice-daily milking on mammary enzyme activity, cell population and milk yield in the goat. J Animal Sci. 1987;64:533-9.

45. Thompson I, Ollier S, Zhao X, Lacasse P. Effects of milking frequency and prolactin on milk production and expression of prolactin receptors in the mammary gland of dairy cows. J Animal Sci. 2015;93:407 [Abstr. T271].

46. Boutinaud M, lollivier V, Finot L, Bruckmaier RM, Lacasse P. Mammary cell activity and turnover in dairy cows treated with prolactin-release inhibitor quinagolide and milked once daily. J Dairy sci. 2012;95:177-87.

47. Delamaire E, Guinard-Flament J. Longer milking intervals alter mammary epithelial permeability and the udder's ability to extract nutrients. J Dairy Science. 2006;89:2007-16.

48. Convey EM. Serum hormone concentrations in ruminants during mammary growth, lactogenesis, and lactation: a review. J Dairy Sci. 1974;57:905-17.

49. CANILEC. Estadísticas del sector lácteo 2010-2018. Cámara Nacional de Industriales de la Leche, marzo, 2019. México.

50. Lopes MA, Nogueira TM, Barbosa GL. Economic viability of the third milking in systems of production using closed-circuit mechanical milking. Rev Ceres Viçosa. 2014;61:544-51.

51. Caixeta LS, Bicalho RC. A pilot study to determine the production and health benefits of milking visibly lame cows twice daily compared with three times daily. Can J Vet Res. 201 1;75:233-6. 